

\title{
With Emotions, We Learn: Understanding Emotions in Learning English as A Second Language (ESL)
}

Zulaikha Mohd Mokhtar, Muhammad Syawal Amran, Maryam Jamila Roslee

To Link this Article: http://dx.doi.org/10.6007/IJARPED/v10-i3/9932

DOI:10.6007/IJARPED/v10-i3/9932

Received: 21 June 2021, Revised: 23 July 2021, Accepted: 15 August 2021

Published Online: 27 August 2021

In-Text Citation: (Mokhtar et al., 2021)

To Cite this Article: Mokhtar, Z. M., Amran, M. S., \& Roslee, M. J. (2021). With Emotions, We Learn: Understanding Emotions in Learning English as A Second Language (ESL). International Journal of Academic Research in Progressive Education and Development, 10(3), 361-372.

Copyright: (C) 2021 The Author(s)

Published by Human Resource Management Academic Research Society (www.hrmars.com)

This article is published under the Creative Commons Attribution (CC BY 4.0) license. Anyone may reproduce, distribute, translate and create derivative works of this article (for both commercial and non-commercial purposes), subject to full attribution to the original publication and authors. The full terms of this license may be seen at: http://creativecommons.org/licences/by/4.0/legalcode

Vol. 10(3) 2021, Pg. 361 - 372

http://hrmars.com/index.php/pages/detail/IJARPED

JOURNAL HOMEPAGE

Full Terms \& Conditions of access and use can be found at http://hrmars.com/index.php/pages/detail/publication-ethics 


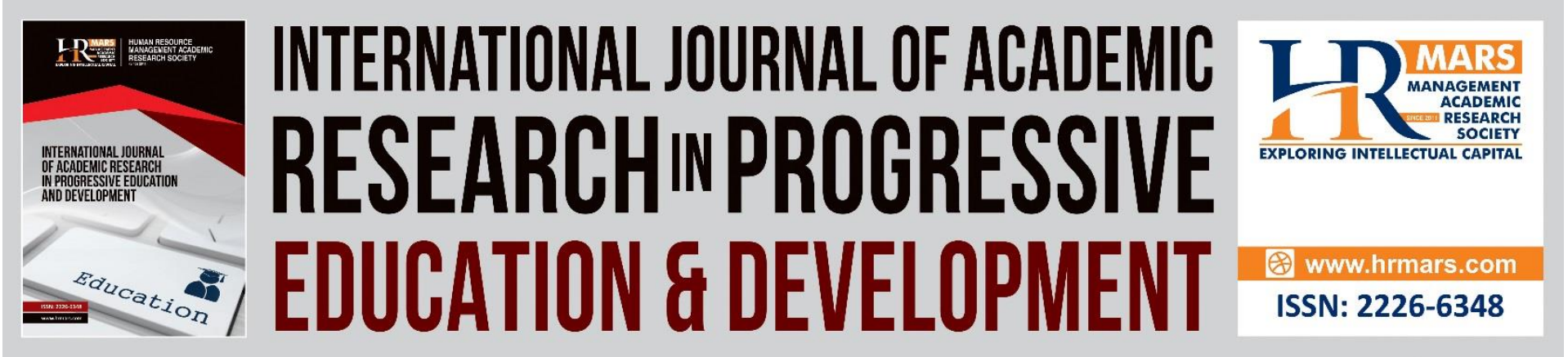

\title{
With Emotions, We Learn: Understanding Emotions in Learning English as A Second Language (ESL)
}

\author{
Zulaikha Mohd Mokhtar, Muhammad Syawal Amran, Maryam \\ Jamila Roslee \\ Faculty of Education, Faculty of Education National University of Malaysia, Selangor, \\ Malaysia. \\ Email: syawal@ukm.edu.my
}

\begin{abstract}
The English proficiency level of ESL learners will be affected by enrolling emotions in English language classes. The aim of this research is to analyse the dominant emotions in learning English as a Second Language (ESL) through reading and writing skills by focusing on three positive emotions (enjoyment, hope and pride) and three negative emotions (anxiety, shame and boredom). Thus, a quantitative research design was carried out by involving $(n=120)$ preservices teachers from a public university in Malaysia. The results revealed that the dominant positive emotions in learning English reading skill was pride while the dominant positive emotions in learning English writing skill was hope. Meanwhile, both skills shared the same emotion of anxiety as the dominant negative emotions. The findings of this study strongly supported the involvement of emotions in the ESL settings. Hence, ESL educators are encouraged to design and formulate an engaging learning environment that ignites more activating positive emotions than negative emotions in the educational settings which would result in better enhancement mainly in the context of ESL learning.
\end{abstract}

Keywords: Emotions, Language, Pride, Hope, Anxiety

\section{Introduction}

In current years, mastering English language has been a universal and prevalent tendency when people consider it as a ticket to one's upcoming accomplishment as there is a growing number of people swarm into the tide of English learning all over the countries (Kong, 2009). English acquisition has become effectively vital that the country of Malaysia agrees attaining English language proficiency and obtaining English soft skills among the students are priority towards the nation building (Thirusanku \& Yunus, 2017). Stated in the National Education Philosophy of Malaysia (1996), education in Malaysia is an ongoing endeavour to grow people's capacity in a holistic way to create mentally, spiritually, emotionally and physically healthy individuals. Hence, teacher plays important roles in being emotionally stable as well because Cyril (2018) asserts that emotionally mature teachers are likely to produce 
emotionally balanced learners. Besides, the terms of emotions are characterized as actions which are closely related to the communication development as well as physical skills in around an intergroup setting (Knaller, 2017). They play critical roles in the teaching and learning process as they put a huge impact on learners' motivation, their self-regulation and students' academic achievement (Rientis \& Rivers, 2014). Therefore, emotions in the ESL context are expected to attract the teaching and learning process because Maidment and Crisp (2011) find that emotions provide some features of planning as well as maintaining responses towards significant conditions by supplying inspirational and functional energy through concentrating attentiveness and regulating thoughts, thus finally activating actionrelated wishes and intentions.

It is worth noting that all emotions are adaptive and have the potential to contribute in growth and well-being (Maclntyre \& Vincze, 2017). For instance, Reza et al. (2016) study reveals that a positive triggering feeling such as enjoyment can boost interest and motivation. Previous research exploring the relationship between the states of emotions and intellectual achievement have shown that positive emotions such as enjoyment and hope contribute to supple thinking, enough capacity to generate thoughts along with the involvement in individual's regulatory and self-recognizing approaches (Pekrun et al., 2007). Besides, pride is caused by the impression of an individual when they accomplish several forms of worth individual results and other personal value for themselves (Stracke \& Ross, 2016). To add, Muris and Meesters (2014) agree that pride provides an essential self/other distinction when the person has accomplished something of importance to himself or something that is valued by others as valuable and good, thereby enabling and encouraging an increase in personal assurance and developing the interpretations of others. Negative emotions, on the other hand, influence the motivation, focus and use of learning strategies by students (Maclntyre \& Vincze, 2017). Take boredom for example, this feeling is activated once learners are not aware of any positive or negative meaning during the process of classroom task (Brookes, 2010).

Meanwhile, anxiety is correlated with language learning as it is experimented vastly in educational fields and influences the achievement and success of learners in tasks related to language skills (Pekrun, 2002). Also, Pekrun further asserts that anxiety has adverse effects on reading as perceptive skills and it is most probably that fewer writings would be composed by learners who have greater levels of writing anxiety. Besides, Stroud and Wee (2007) claim that linguistic shame which is recognized as a sense of shame associated with language use especially in students who speak Malay-speaking English language, has been identified to be ultimately afraid of their peers' shaming habits when English language is directly implemented during the socialisation settings. Thus, a learner in the similar study has described this situation: "So it is like the common language is Malay, then I should not be talking like one clever person, superior. If then they will think I am such a snob."

Furthermore, since emotions are grouped as such according to how they are generally viewed, the discrepancy between positive and negative emotions may be inevitably complicated (Ross \& Stracke, 2016). Students are believed to encounter both positive and negative feelings in English classes that have an effect on learners' English performance (Ismail, 2015). In details, the states of emotional put a major effect towards academic and learning aspects since accomplishment and acquisition are the key roots of ones' feelings in 
this era (Reza et al., 2016). In addition, Rienties and Rivers (2014) have stated that feelings can happen in any region at any stage of the learning process and could lead to entirely different, even opposite, emotions for English learners. Consequently, emotions influence students' cognitive processes and performance, as well as their psychological and physical health (Pekrun et al., 2011). In this regard, it is proven that emotions have major control towards a person in determining either he or she continues learning a language or proceed doing an exercise in a language classroom (Reza et. al., 2016).

However, there has been no systematic research on how language skills such as reading and writing can evoke emotions such as enjoyment, hope, pride, anxiety, shame and boredom. In Pekrun's et al (2011) research on emotions and Mathematics, they insist emotions regulate the attention of students, influence their desire to learn, alter the options of learning methods and affect their learning self-regulation. Attached the previous research on emotions, there has been limited research that underlines how emotions might affect learners' English reading and writing skills as the study is not taken into consideration (Driscoll \& Powell, 2016). This current study shows a great interest in examining reading and writing skills as Sadiku (2015) believes they are significantly interrelated and work simultaneously as tools in effective English competencies levels. Thus, it is a need to have an extended scope for this study and examine the objectives regarding the dominant level of positive and negative emotions through reading and writing skills in an ESL learning context. Therefore, this research aims to determine the dominant emotions in English as a Second Language (ESL) learning specifically through reading and the skills of writing. There are six learning-related emotions altogether which are positive emotions; enjoyment, hope, pride and negative emotions; anxiety, shame and boredom.

\section{Literature Review}

Emotions play crucial roles as they are said to be context-dependent and personalized reactions towards the particular conditions, things or humans within academical contexts (Lopez, 2011). During this dynamic process of emotions, language learners are likely to experience a variety of emotions and it is crucial to pay attention to emotions which are triggered by language learning instructions because when teachers fail to understand the value of the emotions of students, they fail to appreciate a vital force in the learning of students (Damasio, 2007). During learning activities, the diverse emotions that students are able to experience may trigger various affective reactions in students. It has been proved by Lopez (2011) that students prefer to change their expectations and be able to undertake new tasks in the future if they feel that the activities are challenging but at the same time, they could experience the feelings of enjoyment or pride when doing it. Lopez's study further explained that therefore, the emotions appeared in this assessment process give students the motivating energy to direct their actions and modulate their thoughts as it will decide their continuation or end towards the learning.

Moreover, the role of emotions in ESL learning is significant as it determines an individual to decide either continue learning a second language or to proceed on an activity in language classroom settings (Lopez \& Aguilar, 2013). The given opinion is supported by Ismail (2015) that students' participation in English classes attended to both positive and negative emotions really put a huge effect on their performance in English language learning. Ismail's statement is further agreed by Ross and Rivers (2018) by asserting that a huge influence of emotions 
towards the learning of ESL might occur via the application of neurology and psychology towards the contents learnt. The findings are gained due to a number of researches that have been carried out according to Ross and Rivers (2018), which resulted towards an increasing engagement in ESL acquisition relating with positive and negative emotions.

Therefore, Ismail's research has come out with a justification that teachers of the English language need to take into account the academic movements of their students and accept them as part of the education in order to minimize negative feelings and provide their classrooms with the effectiveness of positive emotions. On the other hand, there is an assertion made by Lopez and Aguilar (2013) who take the stance that, not enough attention is given to the topic of emotions in language learning. Concerning this situation, Pishghadam (2011) indicates that an extended scope on this issue is needed as it is believed that the English language classroom along with process of teaching and learning English can be a platform for developing human skills in emotions. Relevantly, it is vital to know that different students even in the same situations, may experience different emotions. This is due to Pekrun's (2014) belief that emotions involve subjective experiences which vary between individuals. For instance, in a classroom, one student may feel enjoyment when doing English vocabulary hand-outs, whereas another student feels bored.

The same research by Pekrun addresses that these kinds of differences happen in individuals due to some factors such as culture, ethnicity, gender, membership in school and membership in the classroom itself. In this current study, there are three positive emotions that are being discussed which are enjoyment, hope and pride. In a study done by Pekrun and Goetz (2011), positive emotions are the feelings which are pleasantly encountered by the three previously described emotions are classified as activating positive emotions. Meanwhile, negative emotions like anxiety, shame and boredom are the opposite as they are unpleasantly experienced. Therefore, attending emotions in ESL classroom is significant as they affect learners' tendency to relax, investigate, tie-up social connection, enhance concentration and understanding as well as optimizing the educational processes (Reilly \& Rosas, 2019).

\section{Methodology}

The aim of this research is to analyse the dominant positive and negative emotions experienced among the participants in learning English as a Second Language (ESL) through the skills of reading and writing. There are two research objectives in this study which are i) to identify the dominant positive and negative emotions in learning English reading skills and ii) to identify the dominant positive and negative emotions in learning English writing skills. This study applied a quantitative research design for the survey. A collection of survey data from 120 undergraduate pre-services teachers from a public university in Malaysia was carried out and participants' selection was a crucial process to provide relatable responses on the contexts of the study done. Hence, the research instrument used to measure the dominant positive and negative emotions in learning English reading and writing skills was a questionnaire. It was adapted from Achievement Emotions Questionnaire (AEQ) (Pekrun et al., 2011). Generally, there are three sections for the research instruments. Sections $A$ was a set of demographic questions that collected participants' profiles. Meanwhile, Section B consisted of 24 items that measured positive and negative emotions in learning English reading skills such as enjoyment, hope, pride, shame, anxiety and boredom.

Lastly, Section C consisted of 24 items that measured the similar positive and negative emotions in learning English writing skills. In total, the online survey created consisted of 48 
Likert-scale statements with 24 statements for each skill respectively. Four statements are attached per emotions, making it 24 statements altogether for each skill. In addition, the questionnaire instrument was scored on a 4-point Likert scale which was labelled as 4Strongly Agree, 3-Agree, 2-Disagree and 1-Strongly Disagree. The results of the pilot study showed that Cronbach's alpha value for the positive and negative emotions variables in this research are in the value of 0.90. It was aligned with Sekaran \& Bougie (2010), the excellent reliability coefficient range of Cronbach's alpha was between 0.80 and above.

\begin{tabular}{llcl}
$\begin{array}{l}\text { Results and Discussion } \\
\text { Demographic }\end{array}$ & Course & Sex (\%) & \\
\cline { 2 - 4 } & Male & Female \\
\hline $\begin{array}{l}\text { Sports and } \\
\text { Recreation }\end{array}$ & 12 & 88 \\
$\begin{array}{l}\text { Special } \\
\text { Education }\end{array}$ & 20 & 80 \\
\hline
\end{tabular}

\section{Research Findings}

The results of the study are reported based on the following two research objectives: i) to identify the dominant positive and negative emotions in learning English reading skills, ii) to identify the dominant positive and negative emotions in learning English writing skills.

\section{Emotions in Learning English in Reading Skills}

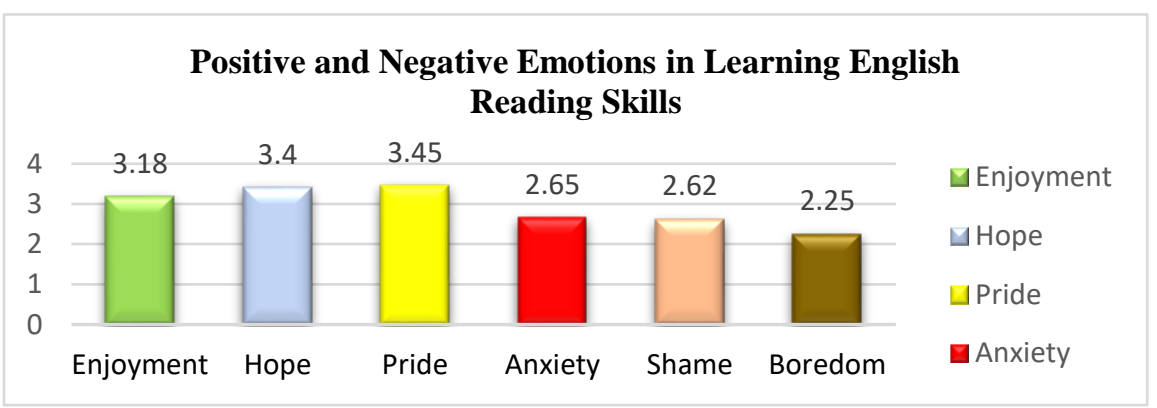

Figure 1. Positive and Negative Emotions in Learning English Reading Skills

Figure 1 displays the descriptive analysis of positive emotions (enjoyment, hope and pride) and negative emotions (anxiety, shame and boredom) in learning English reading skill. For the three positive emotions, the findings show that the emotion of enjoyment has a mean of 3.18 and a standard deviation value (SD) of 0.38 . This value is followed by the moderate value in hope (mean $=3.40, S D=0.46$ ) and pride (mean $=3.45, S D=0.49$ ). Therefore, these results reveal that the dominant positive emotions in learning English reading skill is pride due to the highest value of mean (3.45) as stated in the chart.

On the other hand, as for negative emotions, the results identify that anxiety has a mean value of 2.65 and a standard deviation value (SD) of 0.69 . This value is followed by shame (mean $=2.62, \mathrm{SD}=0.73$ ) and the lowest level of value is found in boredom (mean $=2.25, \mathrm{SD}$ $=0.72$ ). Hence, these results indicate that the dominant negative emotions in learning English reading skill is anxiety due to the highest value of mean (2.65) as stated in the chart. 


\section{Emotions in Learning English in Writing Skills}

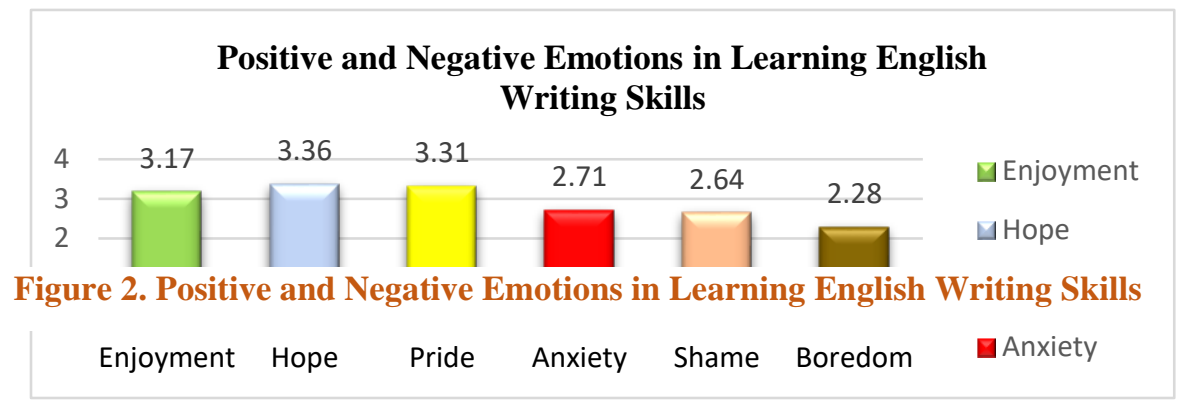

Figure 2 presents the descriptive analysis of positive emotions (enjoyment, hope and pride) and negative emotions (anxiety, shame and boredom) in learning English writing skill. For the three positive emotions, the findings show that the emotion of enjoyment has a mean value of 3.17 and a standard deviation value (SD) of 0.44 . This value is followed by the highest value in hope (mean $=3.36, \mathrm{SD}=0.60$ ) and the moderate value in pride (mean $=3.31, \mathrm{SD}=0.50$ ). Therefore, these results reveal that the dominant positive emotions in learning English writing skill is hope due to the highest value of mean (3.36) as stated in the chart.

On the other hand, as for negative emotions in learning English writing skill, the results identify that anxiety has a mean value of 2.71 and a standard deviation value (SD) of 0.74. This value is followed by a moderate value in shame (mean $=2.64, \mathrm{SD}=0.76$ ) and the lowest level is found in boredom (mean $=2.28, S D=0.77$ ). Hence, these results indicate that the dominant negative emotions in learning English writing skill is also anxiety due to the highest value of mean (2.71) as stated in the chart.

\section{Discussion}

The results indicate that pride is identified as a dominant positive emotion in the acquisition of English reading skills among the participants. It is proven by Piniel and Albert 2018 that pride is categorized as a positive and activating outcome-focused emotion which is experienced after receiving evaluation in language learning. In light of Pekrun and Goetz's (2002) findings, it has been found that pride is strongly associated to the academic performance of students. Those previous findings are in line with the present research as participants dominantly rated pride due to their achievement in getting correct answers in English reading tasks and the ability to read English text during ESL classroom. Concerning this result, pride may arise in the context of reading skills activities such as reading comprehension tasks since Tracy and Robins (2007) believe it happens due to the attitudes of ESL learners when achieving favourable results to themselves. The experience of accomplishmentoriented pride in reading skills may also influence ESL learners to grow strong self-resilience, avoid the habit of racism, facilitate individual learning performance and build meaningful plus positive relationship among the people (Winkler, 2012). Consequently, these findings agree with the idea of Broaden-and-Build theory (1998) that the positive emotional gradual experience such as pride can enhance learners' behaviours, reinforce academic competency and it perfectly aligns with the third core propositions identified in this theory which is promoting self-psychological resilience.

Meanwhile, it is valuable to identify anxiety as the dominant negative emotions in learning English reading skill as it is equivalent with the instruments used as participants agree that they feel worried if they could not understand the reading passage, feel panic when doing 
reading activity in class and feel uneasy if they encounter unfamiliar words in the reading passage. Mindful of Jalongo and Hirsh's (2010) insight, this result explains the similar way as classical conditioning works since reading and anxiety are related as beginning impartial stimulus (e.g. reading tasks) that is consistently combined along with detrimental unconditional impulse (e.g. peer discrimination). As a result of this pairing, it contributes in learner's ability to develop a connection between reading and anxiety because they render a sense of dread and uncomfortable feeling when attempting reading tasks. In the current study, reading anxiety occur among the participants as they encounter challenges to comprehend the reading texts. To add, a study by Mohd. Zin and Rafik (2010) elaborate that it happens due to a condition when reading texts are too long, complex and contain overflowing information. Consequently, learners with reading anxiety are more likely to impede reading concentration capacity and develop distractibility of ESL readers (Sellers, 2000). Thus, the overall impact of reading anxiety towards ESL learners' proficiency level can also distract their reading activities scores.

Besides, the results display that hope is the dominant positive emotions in acquiring English writing skills and it is perceived as success-related emotions that strengthen self-confidence over time, such as learners who are hoping for success (Pekrun, 2014). The reported findings by Pekrun are in line with the current research when participants express hope as their dominant positive emotions which motivate them to master their English writing skills, present various information in their writing and hoping that their English essays are understandable as well as grammatically correct. It is asserted by Mastan and Maarof et al (2017) that ESL learners might encounter a few challenges during the process of writing skills because they are most likely unable to systematically express themselves, write with correct flows of ideas and appreciate the writing process. These conditions are impulsive factors which stimulate hope emotion among ESL learners that later express the feeling of hope towards individual writing skills improvement. Concerning this issue, hope is believed to be profoundly interrelated in ESL learning experience such as the skills of writing because it develops strong aspirations towards language application of ESL learners proficiently (Ross \& Rivers, 2018). Consequently, when learners attend the emotions of hope concerning their writing skills performance, it displays strong correlations with the notion of motivation. Hence, learners are possible to be influenced in building concrete vision of their ESL proficiency level and be able to present various information in their writing.

On the other hand, anxiety is identified as the dominant negative emotions in learning English writing skills. This result portrays the relevance of Kara's (2013) findings that explain, learners develop anxiety in writing skills because they are lacking of necessary strategies like organizing ideas, gathering information, combining ideas and believe that they may fail the writing exercise. It is aligned with this current research when participants agree that they feel worried of the errors they might do in essay writing, feel nervous when doing writing activity, get panicked when seeing other friends busy writing their essays during exam. In the same vein, Karakaya and Ulper (2011) has further elaborated that anxiety in writing skills exists as a result of worrying about receiving negative evaluation because most of the ESL learners primarily encounter the feeling of uneasiness towards the upcoming interpretation from peers and teachers about their writing results. Therefore, writing anxiety is observed as an alarming and significant issues due to its high probability to affect learners' production of written tasks. With regard to this issue, Aikman (1985) suggests that learners' writing anxiety levels are possible to be reduced by utilizing proper writing tasks and putting more 
concentration towards the writing exercises. Encouraging ESL learners to read more books may also help in minimizing writing anxiety levels because Yaman (2010) found positive substantial variations between the levels of writing anxiety and the quantity of books read by students per month.

In a nutshell, it is approved that the emotion of pride is the dominant positive emotion in learning English reading skills while anxiety is identified to be the dominant negative emotion in learning English reading skills. On the other hand, hope is found as the dominant positive emotion in learning English writing skills while anxiety is also reported as the dominant negative emotion in learning English writing skills. In the current study, attending emotions in the ESL classroom is a significant role in order to provide better ESL learning performance towards ESL learners which can directly affect learners' level of proficiency as well as their English literacy development mainly in the context of English language.

\section{Conclusion}

Emotions hold essential roles towards the language performance of ESL learners. In this study, researcher had examined the dominant positive and negative emotions in two major skills of English which are reading and writing skills. Generally, the findings of this study strongly supported the involvement of emotions in the ESL settings which may enhance learners' feelings and direct impactful significant relationship with the language itself. Particularly, this study declared an outlook that the dominant positive emotions in English reading and writing skills such as pride and hope are both classified as the activating positive emotions. This categorization has approved that activating positive emotions such as pride and hope are able to improve learners' attentiveness, employ excitement, utilize profound learning strategies and increase personal regulation during academical settings. In contrast, concerning the dominant negative emotions in English reading and writing skills acquisition which is anxiety, it is then considered as an activating negative emotion. This category of emotion hold by anxiety can assist the application of learning approach and generate motivation to advance learners' good work.

This study has revealed the relevance of attending emotions in ESL learning because the role of emotions must not be neglected especially when it comes to the aspect of English language learning. Hence, ESL teachers are encouraged to design and formulate an engaging learning environment that ignites more activating positive emotions than negative emotions in the educational settings which would result in better enhancement mainly in the context of ESL learning. In terms of the limitation of this study, it must be noted that the scope of the data collection process throughout this research was limited among the undergraduate pre-service teachers from a public university in Malaysia. Also, this research has primarily concentrated on the skills of reading and writing apart from taking all four English skills into the main consideration of this study. As for the future research, this study suggests that it is worth to examine how the positive and negative emotions in ESL learning may influence the memory of ESL learners in learning English language. This might contribute in producing important information to figure out the affecting factors in positive as well as negative emotions and its relationship with ESL learners' memory in learning English language.

\section{References}

Atay, D., \& Kurt., G. (2006). Prospective Teachers and L2 Writing Anxiety. Turkey: Marmara University, Istanbul. 
Bojovic, M. (2010). Reading Skills and Reading Comprehension in English for Specific Purposes, Serbia: University of Kragujevac.

Brookes, G. (2010). Boredom in Writing Class, Journal of Teaching Writing, 145-160.

https://journals.iupui.edu/index.php/teachingwriting/article/view/1149/1109

Bruning, R., \& Horn, C. (2000). Developing Motivation to Write. Educatioana Psychologist, 35 (1), 25-37.

Chang, L. (1994). A Psychometric Evaluation of 4-Point and 6-Point Likert-Type Scales in Relation to Reliability and Validity. University of Minnesota, Applied Psychological Measurement Inc.

Cyril, V. A. (2018). A Study on Emotional Maturity among High School Teachers, International Journal of Pedagogical Studies (IJPS) Vol: 6/Issue: 1

Damasio, A. (2007). We Feel, Therefore We Learn: The Relevance of Affective and Social Neuroscience to Education. Mind, Brain and Education, 1 (1), 3-10.

Decuir, J. T., \& Schutz, P. A. (2010). Inquiry on Emotions in Education, Educational Psychologist, 37:2, 125-134.

Dewaele, J. M., \& Maclntyre, P. D. (2014) Anxiety and Enjoyment in the Foreign Language Classroom. Studies in Second Language Teaching and Learning, 4(2), 237-274.

Driscoll, L., \& Powell, R. (2016). States, Traits and Dispositions: The Impact of Emotion on Writing Development and Writing Transfer Across College Courses and Beyond. Composition Forum 34.

Etherington, M. (2019) Pride in Education: A Narrative Study of Five Finnish Schoolteachers, Canada: Trinity Western University.

Eynde, P., Corte, E., \& Verschaffel, L. (2006). Accepting Emotional Complexity: A SocioConstructivist Perspective on the Role of Emotions in the Mathematics Classroom. Educational Studies in Mathematics, 63(2), 193-207.

Fredrickson, B. L. (2000). Cultivating Positive Emotions to Optimize Health and Well-Being. Prevention and Treatment 3. Retrieved from http://www.rickhanson.net/wpcontent/files/papers/CultPosEmot.pdf

Fredrickson, B. L. (2001). The Role of Positive Emotions in Positive Psychology: The Broadenand-Build Theory of Positive Emotion. American Psychologist, 56, 218-226.

Fredrickson, B. L. (2003). The Value of Positive Emotions: The Emerging Science of Positive Psychology Looks into Why It's good to Feel Good. American Scientist.

Fredrickson, B. L. (2004). The Broaden-and-Build Theory of Positive Emotions. Philosophical Transactions of the Royal Society of London Series B: Biological Sciences.

Fried, L. (2011). Teaching Teachers about Emotion Regulation in the Classroom, Australian Journal of Teacher Education.

Fujieda, Y. (2019). A Pilot Study of Emotions of Writing in L2: Unpacking the Felt Sense of an EFL Writer, Japan: Kyoai Gakuen University.

Fung, H., P. (2015). Which Likert scale should I prefer that of 1-4, 1-5 or 1-7? Retrieved at: https://www.researchgate.net/post/Which_Likert_scale_should_I_prefer_that_of_14_1-5_or_1-7/567cff0f6225ffe11e8b4586/citation/download.

Goetz, T., Frenzel, C. A., Hall, N. C., \& Pekrun, R. (2008). Antecedents of Academic Emotions: Testing the Internal/External Frame of Reference Model for Academic Enjoyment. Contemporary Educational Psychology. 
Greenspan, S., \& Shanker, S. (2004). The First Idea: How Symbols, Language and Intelligence Evolved from Our Primate Ancestors to Modern Humans, Cambridge, MA: Da Capo Press.

Hargreaves, A. (2005). The Emotions of Teaching and Educational Change, Netherlands: Ontario Institute for Studies in Education, University of Toronto.

Atmowardoyo, H. (2018). Research Methods in TEFL Studies: Descriptive Research, Case Study, Error Analysis and R\&D, Journal of Language Teaching and Research.

Ismail, N. M. (2015). EFL Saudi Students' Class emotions and Their Contributions to Their English Achievement at Taif University, Saudi Arabia: International Journal of Psychological Studies.

Izard, C. E. (2001). Emotion Knowledge as A Predictor of Social Behaviour and Academic Competence in Children at Risk. Psychological Science.

Izard, C. E. (2007). Basic Emotions, Natural Kinds, Emotion Schemas and A New Paradigm. Perspectives on Psychological Science, 2, 206-280.

Izard, C. E. (2010). The Many Meanings/Aspects of Emotion: Definitions, Functions, Activation and Regulation. Emotion Review, 2(4), 363-370.

Jalongo, M., R., \& Hirsh., R., A. (2010). Understanding Reading Anxiety: New Insights from Neuroscience, Springer Science \& Business Media.

Kara., S. (2013). Writing Anxiety: A Case Study on Students' Reasons for Anxiety in Writing Classes, Turkey: Anadolu University.

Knaller, S. (2017). Emotions and the Process of Writing: Writing Emotions, Faculty of Arts and Humanities, University of Graz.

Kong, Y. (2009). A Brief Discussion on Motivation and Ways to Motivate Students in English Language Learning, China: International Education Studies.

Lopez, M. G. M. (2011). The Motivational Properties of Emotions in Foreign Language Learning, Colombian Applied Linguistics Journal.

Lopez, M. G. M., \& Anguilar, A. P. (2013). Emotions as Learning Enhancers of Foreign Language Learning Motivation. 15(1), 109-124.

Maclntyre, P., \& Vincze, L. (2017). Positive and Negative Emotions Underlie Motivation For L2 Learning, Kalisz: Department of English Studies, Faculty of Pedagogy and Fine Arts, Adam Mickiewicz University.

Maclntyre, P., \& Gregersen, T. (2012). Emotions that Facilitate Language Learning: The Positive-Broadening Power of the Imagination, Kalisz: Department of English Studies, Faculty of Pedagogy and Fine Arts, Adam Mickiewicz University.

Maidment, J., \& Crisp, B. (2011). The Impact of Emotions on Practicum Learning, New Zealand: Social Work Education.

Malaysian Ministry of Education (2013). Malaysia Education Blueprint 2013-2025, Putrajaya: Kementerian Pelajaran Malaysia.

Maryam, M. (2012). The Role of Emotional Intelligence on English Learning as a Second Language, Iran: Islamic Azad University.

Meng, E. A. (1996). Education in Malaysia 1: National Education Philosophy: Goal and Mission, Putrajaya, Malaysia: Curriculum Development Centre.

Muris, P., \& Meesters, C. (2014). Small or Big in the Eyes of the Other: On the Developmental Psychopathology of Self-Conscious Emotions as Shame, Guilt and Pride. Clinical Child and Family Psychology Review. 
DEVELOPMENT

Vol. 10, No. 3, 2021, E-ISSN: 2226-6348 @ 2021 HRMARS

Fitriana, N. (2011). The Use of Animation in Narrative Writing, Indonesia: University of Sebelas Maret.

Nezlek, J. B., \& Kuppens, P. (2008). Regulating Positive and Negative Emotions in Daily Life. Williamsburg: College of William and Mary, Department of Psychology.

Pekrun, R. (2014). Emotions and Learning, Belgium: International Academy of Education (IAE) \& Switzerland: International Bureau of Education (IBE).

Piniel, K., \& Albert, A. (2018). Advanced Learners' Foreign Language-Related Emotions Across the Four Skills, Budapest: Eotvos University.

Pishghadam, R. (2011). Introducing Applied ELT as a New Approach in Second/Foreign Language Studies, Iranian EFL Journal, 7(2), 8-14.

Reilly, P., \& Rosas, J. S. (2019). The Achievement Emotions of English Language Learners in Mexico, Singapore: Centre of Language Studies, National University of Singapore.

Rienties, B., \& Rivers, B. A. (2014). Measuring and Understanding Learner Emotions: Evidence and Prospects, Learning Analytics Community Exchange (LACE).

Robinson \& Jenefer. (2010). Emotion and the Understanding of Narrative, in: Hagberg, Garry, L., Walter, Oxford, 71-92. Rome, D., I. (2014). The Bilingual Mind: What It Tells Us About Language and Thought. Cambridge, UK: Cambridge University Press.

Ross, A. S., \& Stracke, E. (2016). Learner Perceptions and Experiences of Pride in Second Language Education. Australia: Australian Review of Applied Linguistics.

Ross, A. S., \& Rivers, D. J. (2018). Emotional Experiences Beyond the Classroom: Interactions with the Social World. Kalisz: Studies in Second Language Learning and Teaching.

Sadiku, M. L. C. (2015). The Importance of Four Skills Reading, Speaking, Writing, Listening in a Lesson Hour, Albania: European Journal of Language and Literature Studies.

Schutz, P. A., \& Pekrun, R. (Eds.). (2007). Emotion in Education, San Diego, CA: Academic Press.

Sekaran, U., \& Bougie, R. (2010). Research Methods for Business: A Skills Building Approach, Italy: Library of Congress Cataloging in Publication Data.

Sellers, V. (2000). Anxiety and Reading Comprehension in Spanish as a Foreign Language. Foreign Language Annals.

Stroud, C., \& Wee, L. (2007). A Pedagogical Application of Liminalities in Social Positioning: Identity and Literacy in Singapore. TESOL Quarterly.

Thirusanku, J., \& Yunus, M. M. (2017). Status of English in Malaysia, Malaysia: Canadian Center of Science and Education.

Tracy, J. L., \& Robins, R. W. (2007). The Prototypical Pride Expression: Development of A Nonverbal Behavioural Coding System. Emotion, 7, 789-801.

Winkler, E. (2012). Learning Race, Learning Place: Shaping Racial Identities and Ideas in African American Childhood, London, England: Rutgers University Press.

Yaman, H. (2010). Writing Anxiety of Turkish Students: Scale Development and the Working Procedures in Terms of Various Variables. International Online Journal of Educational Sciences, 2 (1), 267-289.

Mohd. Zin, Z., \& Rafik-Galea, S. (2010). Anxiety and Academic Reading Performance among Malay ESL Learners. Journal of PanPacific Association of Applied Linguistics, 14(2), 4158. 